\title{
STREET TREE HEALTH ASSESSMENT SYSTEM: A TOOL FOR STUDY OF URBAN GREENERY
}

\author{
E. BATALA \& T. TSITSONI \\ Faculty of Forestry and Natural Environment, Laboratory of Silviculture, Aristotle University, Thessaloniki, Greece.
}

\begin{abstract}
This study deals with the recording of tree health and the evaluation of the greenery ratio, with a view to increase it, in three representative street trees in Thessaloniki city, North Greece. The three street trees are representative because of the species composition and the health of the trees on one hand and the flow of traffic on the other hand. The three street trees investigated in this study are located along three central roads of Thessaloniki city, namely Nikis Avenue, Egnatia Street and Karamanli Avenue. The study also includes the formulation of proposals in order to make some improvement in the choice of suitable species so as to increase the amount of greenery in the city. The results show that the most important problems related to tree health in the three streets are the leaves being attacked by insects and fungi as well as dry and broken branches of the crown. The majority of trees have moderate health. The greenery ratio in the three street trees is evaluated by the greenery's surface and volume indicators, which are calculated depending not only on the number of trees but also on the surface and volume of their crowns. Finally, a linear model for the greenery's volume indicator is estimated which depends on tree height, crown length and crown projection on the ground.
\end{abstract}

Keywords: crown surface, tree health, tree species, urban greenery.

\section{INTRODUCTION}

The 20th century was the century of urbanization. Nowadays, it is calculated that more than half of the world's population lives in urban regions and by 2030 the urban population is expected to be twice as large as the corresponding rural population [1-4]. The procedure of urbanization had important natural and spatial effects on the landscape because large parts of it were transformed into urban landscapes and therefore the relationship between human society and the natural environment changed dramatically [5-7]. Urban greenery is of fundamental importance for the quality of life in our ever increasingly urbanized societies [8-10]. Although trees have covered a large part of human settlements throughout history, their great value for humans has only recently been studied [11-13]. More specifically, the term 'urban greenery' refers to open green spaces that are located in the urban web and include parks, street trees and other garden areas [14-16]. Urban greenery beyond the aesthetic and designing uses also offers social and psychological services which are very important for the well being of citizens. Large green areas in the urban and periurban web can reduce the stress of the residents and refresh them [17-20].

The urban environment constitutes a difficult biotope for trees. Environmental pressures decrease the vitality of many species and increase their sensitivity to diseases and parasitic attacks. Trees that grow in cities suffer from the effects of negative ecological factors such as poor soil (compressed and with insufficient or low proportion of humidity and nutrients), polluted atmosphere and vandalism. These problems can only be prevented by choosing the proper species [21-26].

The aim of this study is to record tree health and to evaluate the greenery ratio, with a view to increase it, in three representative street trees in Thessaloniki city, North Greece. The three street trees are representative because of the species composition and health of the tress on one hand and the flow of traffic on the other hand. The three street trees investigated in this study are located along three central roads of Thessaloniki city, namely Nikis Avenue, Egnatia Street and Karamanli Avenue. The ultimate goal of the study is the formulation of proposals in order to make some improvement 
in the choice of suitable species, for their survival in the urban environment, so as to increase the greenery ratio in the city. For this reason a linear model was derived, which express the relationship between the green volume indicator and three tree variables (tree height, crown's beginning height and crown projection).

\section{MATERIALS AND METHODS}

The research took place in the municipality of Thessaloniki, North Greece, and included the study of the street trees along three central roads of Thessaloniki city, namely Nikis Avenue, Egnatia Street and Karamanli Avenue. The three roads were chosen not only because the traffic is dense but also for the species composition, the health and the characteristics of the street trees that are located along them. The first street tree planted in Nikis Avenue is Platanus orientalis, the second street tree planted in Egnatia Street is Celtis australis, and the third street tree planted in Karamanli Avenue includes Albizia julibrissin, Liquidambar orientalis, Cupressus arizonica and the clone Populus $x$ euramericana cv. 'I-45/51'.

The total number of trees on the three roads was 913. Measurements were taken from all trees in Nikis Avenue and from 20\% of the trees in Egnatia Street and Karamanli Avenue (because of the large number of trees), that is, 248 trees, of which 81 trees are from Nikis Avenue, 70 trees from Egnatia Street and 97 trees from Karamanli Avenue (Table 1).

The trees in Egnatia Street and Karamanli Avenue were chosen by systematic sampling. According to this method, one tree from the first five trees of each street tree was selected randomly and afterwards the choice of the sample trees was done per five trees until the sample was completed. Each sampled tree was measured for tree height, tree breast diameter, crown's beginning height and crown dimensions. The crown length, the projection of the crown on the ground and the crown volume were calculated. Assuming that the tree crown is usually modeled as a cone, the crown projection (CP) is the surface of a circle with diameter $d_{i}$ and so it was calculated using the formula $\mathrm{CP}_{i}=\pi / 4 d_{i}^{2}$. The crown diameter $d_{i}$ was calculated using the formula $d_{i}=\left(d_{1}+d_{2}\right) / 2$, where $d_{1}$ and $d_{2}$ are the crown diameters measured from east to west and north to south, respectively. The crown volume (CV) was calculated using the formula $\mathrm{CV}=\mathrm{CP} \times L / 3$, where $L$ is the crown length which results if the crown's beginning height is subtracted from the total tree height $[27,28]$. The product (crown projection of the average tree) $\times$ (number of trees in each road) was characterized as the active greenery's surface, while the product

Table 1: Number of trees of each species, total number of trees and number of sample trees in the three studied roads.

\begin{tabular}{|c|c|c|c|c|}
\hline Road & Species & $\begin{array}{l}\text { Total } \\
\text { number of } \\
\text { trees }\end{array}$ & $\begin{array}{l}\text { Number of } \\
\text { trees of } \\
\text { each } \\
\text { species }\end{array}$ & $\begin{array}{l}\text { Number of } \\
\text { sample } \\
\text { trees }\end{array}$ \\
\hline Nikis Avenue & Platanus orientalis & 81 & 81 & 81 \\
\hline Egnatia Street & Celtis australis & 347 & 347 & 70 \\
\hline Karamanli Avenue & $\begin{array}{l}\text { Albizia julibrissin } \\
\text { Populus } x \text { euramericana cv. } \\
\text { 'I- } 45 / 51 \text { ' }\end{array}$ & 326 & $\begin{array}{l}185 \\
141\end{array}$ & 65 \\
\hline $\begin{array}{l}\text { Central division of } \\
\text { Karamanli Avenue }\end{array}$ & $\begin{array}{l}\text { Liquidambar orientalis } \\
\text { Cupressus arizonica }\end{array}$ & 159 & $\begin{array}{l}60 \\
99\end{array}$ & 32 \\
\hline Total & & 913 & 913 & 248 \\
\hline
\end{tabular}


(crown volume of the medium tree) $\times$ (number of trees in each road) was characterized as the active greenery's volume $[29,30]$.

The recording of the damage was done according to a specific damage diagnosis catalogue and the tree species were grouped according to their health into four categories: good health (trees without health problems), moderate health (trees with health problems that can be corrected), bad health (trees that must be replaced) and dead [14, 31].

Finally, for each road the greenery's surface indicator (the active greenery's surface divided by the length of the road) and the greenery's volume indicator (the active greenery's volume of the crowns divided by the length of the road) were calculated. The relationship between the volume indicator and three tree variables (tree height, crown's beginning height and crown projection) was derived by a linear model using the statistical program SPSS version 12.0 for Windows.

A presentation of the results of the statistical processing of the data is given by using box and whisker plots. A box and whisker plot is a graph that presents information from a five-number summary (the smallest observation, lower quartile, median, upper quartile and largest observation). This plot is especially useful for indicating whether a distribution is skewed and whether there are potential unusual observations (outliers) in the data set. This type of graph is used to show the shape of the distribution, its central value and its variability. In a box and whisker plot, the ends of the box are the upper and lower quartiles, so the box spans the interquartile range. The median is marked by a vertical line inside the box. The whiskers are the two lines outside the box that extend to the highest and lowest observations. The position of the median in the plot defines whether a distribution is skewed or normal. If the median is in the middle of the box, then the data distribution is normal. If the median is close to the lower end of the box, then the data distribution has a positive skewness. On the other hand, if the median is close to the upper end of the box, then the data distribution is negatively skewed $[32,33]$.

\section{RESULTS}

Box and whisker plots of tree height values and tree breast diameter values in the three central roads and the central division are depicted in Fig. 1. The figure indicates that the distribution of tree height data is normal in Egnatia Street while the distribution of tree breast diameter data is normal in Nikis Avenue and in the central division of Karamanli Avenue.

Box and whisker plots of tree height values and tree breast diameter values of the six tree species are depicted in Fig. 2. The figure indicates that the distribution of tree height data is normal in the species Celtis australis (species 2) and Populus x euramericana cv. 'I-45/51' (species 6) while the distribution of tree breast diameter data is normal in the species Platanus orientalis (species 1), Cupressus arizonica (species 5) and Populus x euramericana cv. 'I-45/51' (species 6).

The health problems that the trees of each species had are presented in Figs 3-8. In each figure, each problem is depicted using the code number shown in Table 2.

The results show that the most important problems in the three street trees are the following:

- Insect and fungal damage: This problem is most evident in Platanus orientalis and the clone Populus $x$ euramericana cv. 'I-45/51'.

- Dry and broken branches of the crown: This problem is most evident in the trees of the species Celtis australis, Albizia julibrissin, Liquidambar orientalis, Cupressus arizonica and the clone Populus $x$ euramericana cv. 'I-45/51'.

- Bark damage: This problem is most evident in the trees of the species Celtis australis and Albizia julibrissin.

- Trees whose crown touches the crown of other trees: This is a big percentage in the species Cupressus arizonica and Platanus orientalis. 

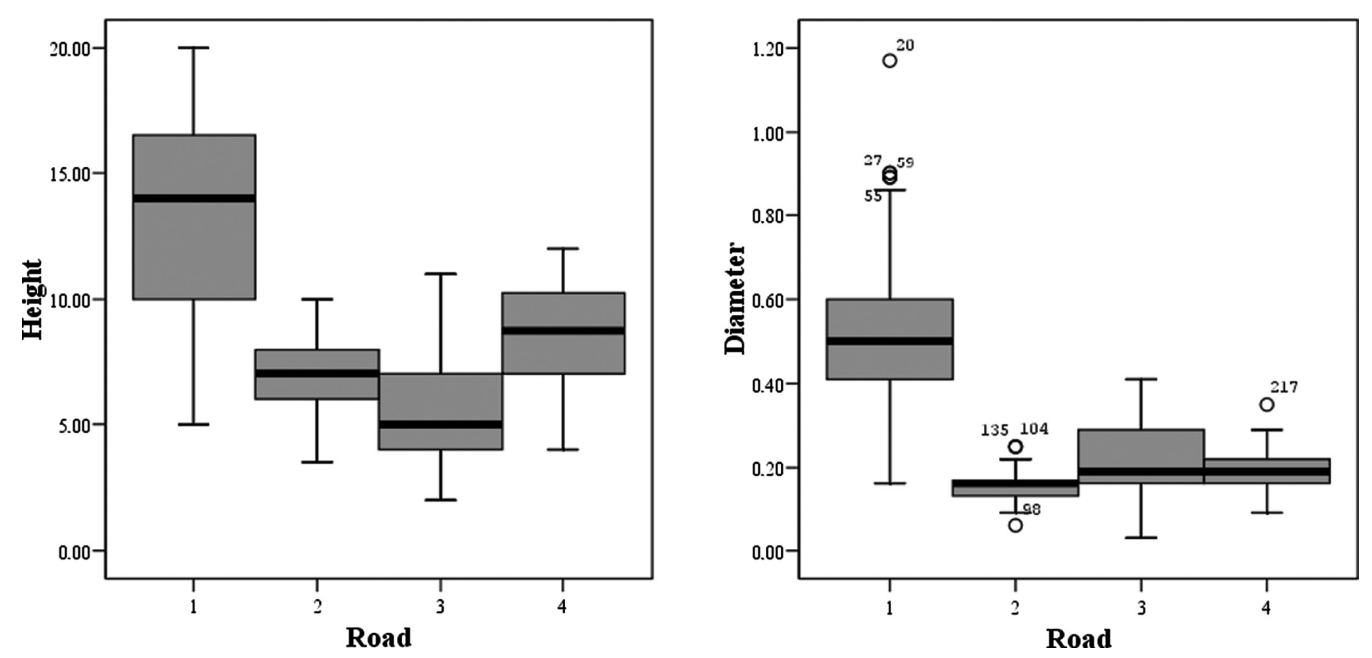

Figure 1: Box and whisker plots of tree height and tree breast diameter for the three central roads and the central division. 1, Nikis Avenue; 2, Egnatia Street; 3, Karamanli Avenue; 4, central division of Karamanli Avenue.
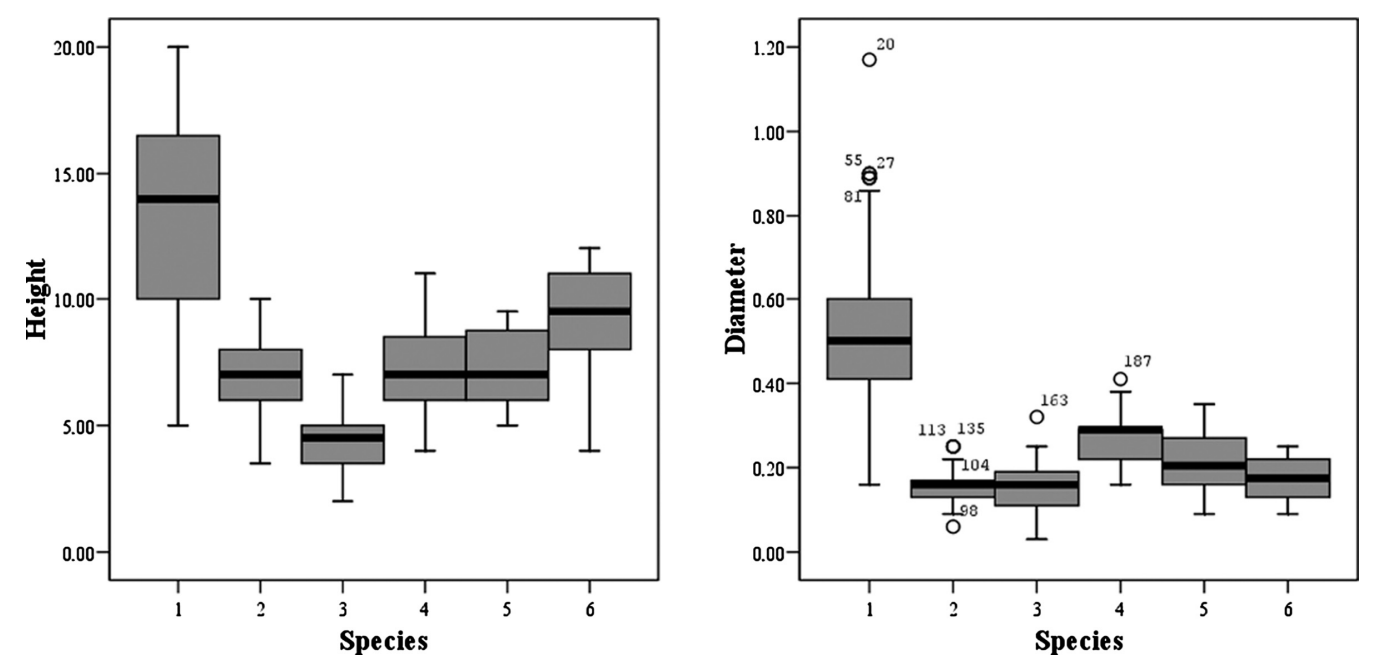

Figure 2: Box and whisker plots of tree height and tree breast diameter for the six silvicultural species. 1, Platanus orientalis; 2, Celtis australis; 3, Albizia julibrissin; 4, Liquidambar orientalis; 5, Cupressus arizonica; 6, Populus x euramericana cv. 'I-45/51'.

The health of the trees belonging to the species Platanus orientalis, Celtis australis and Cupressus arizonica was characterized as moderate while the majority of the trees belonging to the species Albizia julibrissin, Liquidambar orientalis and Populus $x$ euramericana cv. 'I-45/51' have a good health.

The values of the greenery's surface and volume indicators are the highest in Nikis Avenue, which consists of Platanus orientalis. 
Percentage of occurrence

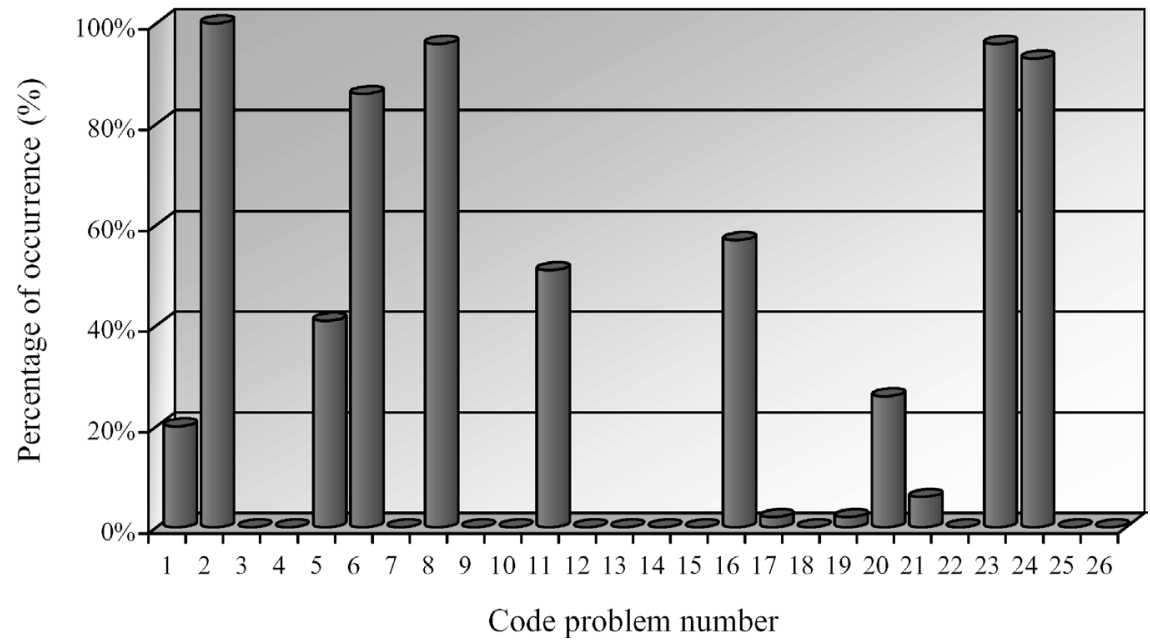

Figure 3: Platanus orientalis problems.

$\square$ Percentage of occurrence

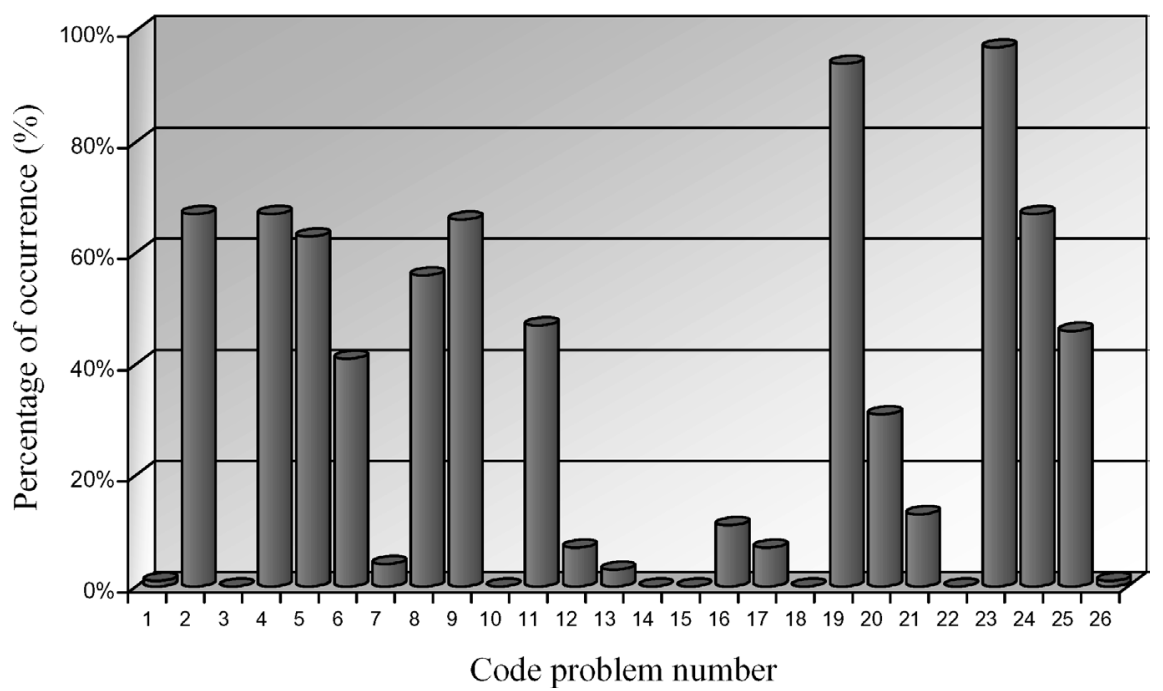

Figure 4: Celtis australis problems. 
$\square$ Percentage of occurrence

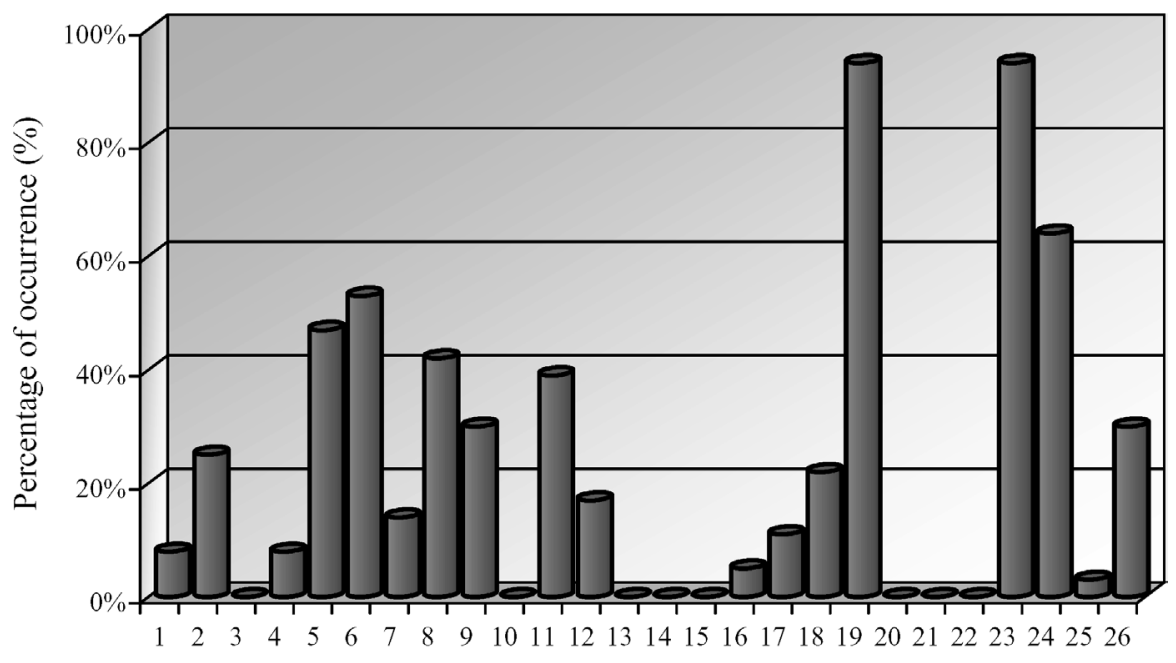

Code problem number

Figure 5: Albizia julibrissin problems.

$\square$ Percentage of occurrence

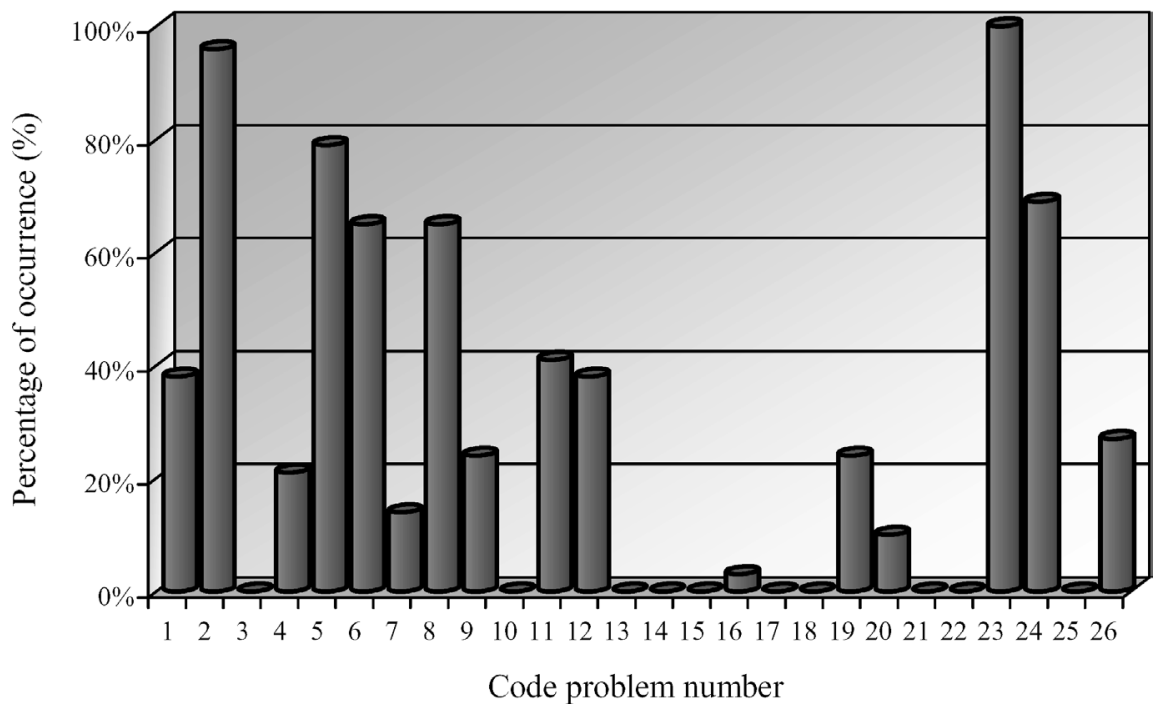

Figure 6: Populus x euramericana cv. 'I-45/51' problems. 
$\square$ Percentage of occurrence

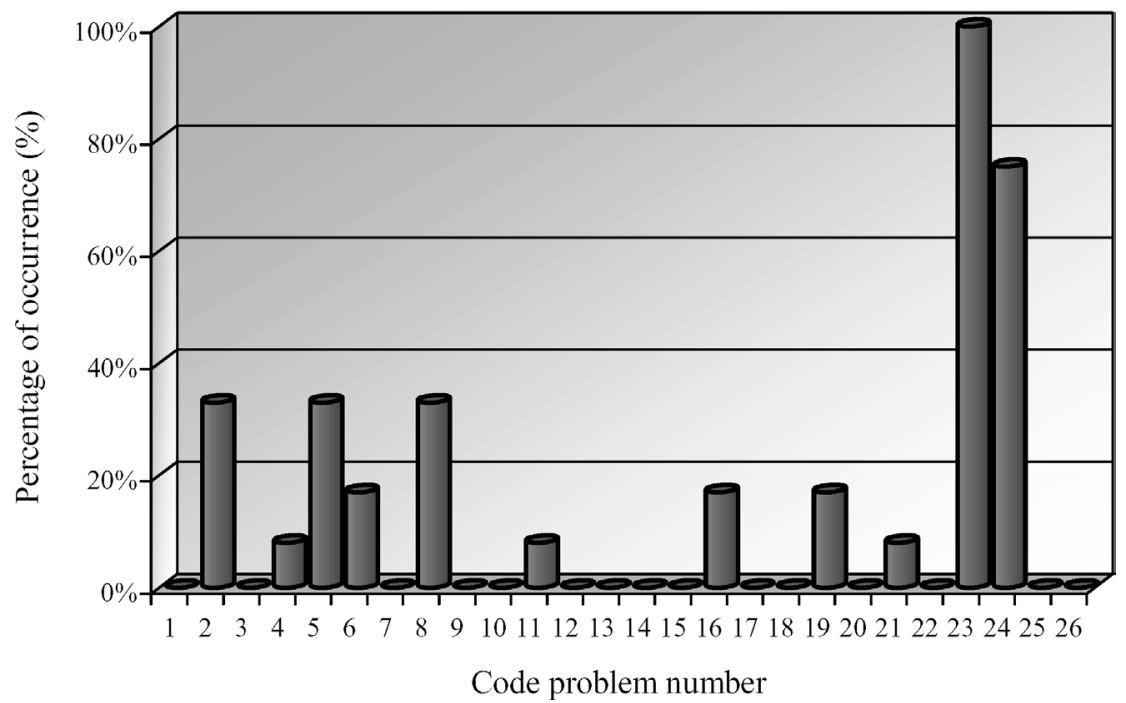

Figure 7: Liquidambar orientalis problems.

$\square$ Percentage of occurrence

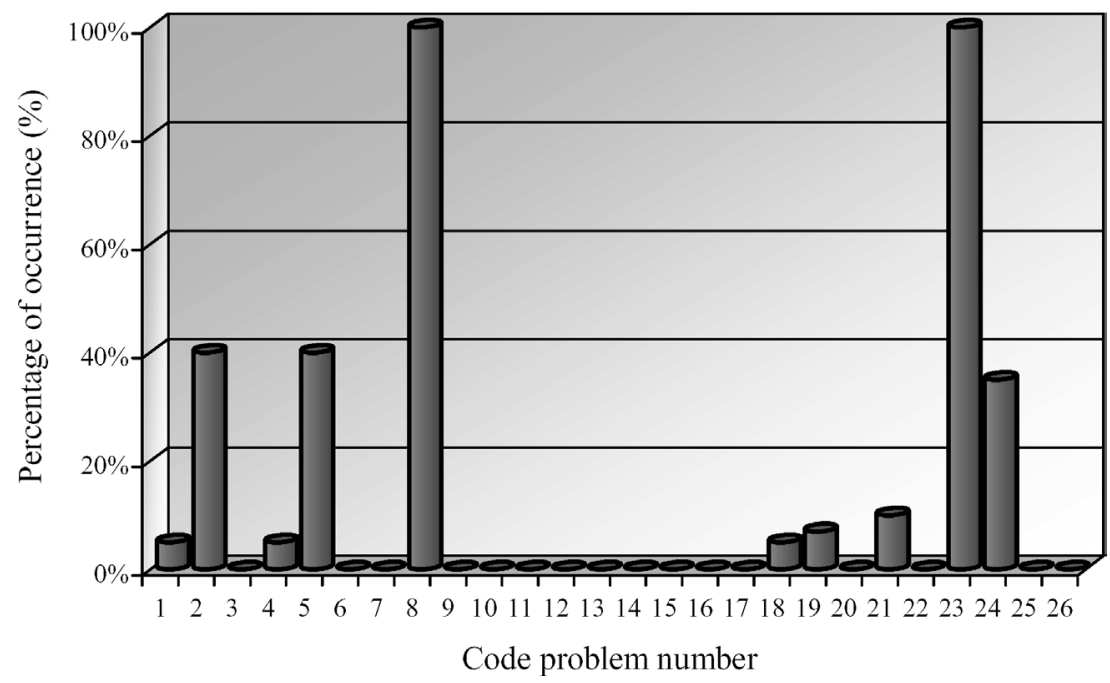

Figure 8: Cupressus arizonica problems. 
Table 2: Diagnosis catalogue of tree health problems and damage.

\begin{tabular}{ll}
\hline 1: Drying out of the crown & 14: Soil removal \\
2: Insect and fungal damage & 15: Root damage due to construction work \\
3: Ivy on trunk & 16: Pavement damage due to roots \\
4: Tree too close to road & 17: Root damage \\
5: Long crown depth close to asphalt surface & 18: Fluid secretion on trunk \\
6: Crown width over road & 19: Bark damage \\
7: Tree too close to buildings & 20: Tree decay \\
8: Crowns touching each other & 21: Narrow bifurcation \\
9: Crowns touching buildings & 22: Water retention in bifurcation \\
10: Damage from construction & 23: Dry and broken branches \\
11: Trees too close to cables or light source & 24: Spreading branches \\
12: Inadequate root space depth & 25: Branch tufts due to pruning \\
13: Compaction of soil & 26: Intensive pruning \\
\hline
\end{tabular}

Table 3: Coefficients of the volume indicator model.

\begin{tabular}{|c|c|c|c|c|c|}
\hline \multirow[b]{2}{*}{ Model } & \multicolumn{2}{|c|}{ Unstandardized coefficient } & \multirow{2}{*}{$\begin{array}{l}\text { Standardized } \\
\text { coefficient }(\beta)\end{array}$} & \multirow[b]{2}{*}{$t$} & \multirow[b]{2}{*}{ Sig. } \\
\hline & $B$ & Standard error & & & \\
\hline Constant & -104.048 & 10.179 & & -10.221 & 0.000 \\
\hline Height & 14.640 & 1.058 & 0.350 & 13.836 & 0.000 \\
\hline $\begin{array}{l}\text { Height of the start } \\
\text { of the crown }\end{array}$ & -18.734 & 4.154 & -0.079 & -4.510 & 0.000 \\
\hline Crown projection & 3.481 & 0.119 & -0.701 & 29.197 & 0.000 \\
\hline
\end{tabular}

Table 4: Analysis of variance of the volume indicator model.

\begin{tabular}{lcrrrr}
\hline Model & Sum of squares & d.f. & Mean square & \multicolumn{1}{c}{$F$} & Sig. \\
\hline Regression & $6,911,054$ & 3 & $2,303,684.723$ & $1,183.283$ & 0.000 \\
Residual & $4,750,334$ & 244 & $1,946.858$ & & \\
Total & $7,386,088$ & 247 & & & \\
\hline
\end{tabular}

All model coefficients are significant at the $<0.01$ level of significance.

Finally, using a multiple linear regression and the tree height, crown's beginning height and crown projection as independent variables, the following volume indicator model was estimated: $Y=-104.048+14.64 X_{1}$ (tree height) $-18.73 X_{2}$ (crown's beginning height) $+3.48 X_{3}$ (crown projection), with adjusted $R^{2}=93.5 \%$. The standard errors and the significance of the model coefficients are presented in Table 3, while the analysis of variance is given in Table 4.

\section{DISCUSSION AND CONCLUSIONS}

Urban forestry was developed as a special branch of forestry in North America and was imported to Europe in the 1980s. However, today, the significance and values of urban forestry are not totally recognized and at the same time there is also a lack of comparative research in this sector $[4,17]$. 
With regard to the health condition of street trees in other European cities, the followings observations have been made.

In Brussels, the number of trees in the streets of the city is about 19,500 with about 200-300 trees being replaced every year. The total number of trees that are planted every year by the municipality is approximately $2,500[34,35]$.

In Munich, the most commonly used species for street trees are Tilia cordata, Aesculus hippocastanum, Acer platanoides, Tilia xeuchlora, Robinia pseudoacacia and Fraxinus excelsior. The most important factors that influence the survival of trees planted in the majority of German cities are: (i) the ice-breaking salt, which is very catastrophic for the trees, and so its use should be forbidden; (ii) inadequate root space depth (code number 12); (iii) compaction of soil (code number 13), which causes anaerobic soil conditions; and (iv) the cover of planting surface, which leads to the insufficient airing of the ground and fortifies the desiccation of trees [35, 36].

In Ireland, the Dutch elm disease (code number 2) caused serious damage to many trees in the majority of Irish cities. The fungi Erwinia amylovora and Stereum purpureum have also attacked many street trees. The most commonly used species for street trees in Dublin are Acer platanoides, Platanus x hispanica, Betula spp., Fagus spp. and Sorbus aucuparia. Since 1970-1990 an average of 20,000 trees/year have been planted on the streets and in the open green spaces. Today, 40,000 trees are planted annually and $60 \%$ of them are located along the streets $[35,37]$.

In Budapest, the number of street trees is about 32,000 and the most serious health problems that they have are: (i) ice-breaking salt, (ii) inadequate root space depth (code number 12) and (iii) infected and damaged barks (code number 19) [35, 38].

In Swedish cities, tree plantations are a procedure that has been happening for many years now. The most commonly used genera are Tilia (31.5\%), Acer (13.8\%) and Sorbus (16.9\%). In North Sweden, the genus Betula dominates. The use of elms is rather limited because of the Dutch elm disease [35, 39].

In Finland, the choice of the species that are used in the development of urban greenery is restricted by the harsh northern climate. For this reason, the choice of species aims at the enrichment of the native tree-flora with resilient species, origins and clones. The species composition that is used in the urban area of Finland is very common to that of West and Central Europe, but poorer. The most commonly used species for street trees are Tilia vulgaris, Betula pendula, Acer platanoides, Sorbus aucuparia and Ulmus glabra. It is also estimated that 100,000 trees are planted annually [35, 40].

In the municipality of Thessaloniki, the number of street trees is about 30,000 and the most commonly used species are Sophora japonica (16\%), Albizia julibrissin (15\%), Robinia pseudoacacia (14\%), Acer negundo/Acer pseudoplatanus (12\%), Populus sp. (11\%), Platanus orientalis (5\%), Koelreuteria paniculata (4\%), Celtis australis (3\%), Citrus aurantium (3\%), and Liquidambar orientalis, Tilia tomentosa, Hybiscus syriacus, Ulmus campestris, Olea europea, Cercis siliquastrum (2\%) [26].

The analysis of the results led to the following conclusions about the health and the damage that the species presented as well as to the formulation of proposals to avoid these problems.

The attacks on the leaves of Platanus orientalis by fungi and insects are secondary damage and it is caused mainly by the limited available growing space and the insufficient soil conditions. In Nikis Avenue's street trees, this species forms a very large crown. In order to achieve the normal development of the crown (the crown must be aired and the interactions between crowns must be avoided) and the vertical position of the trunks, a bigger spacing ( $>10 \mathrm{~m})$ should be applied between the trees. The dry and broken branches that the crown of many species (Celtis australis, Albizia julibrissin, Liquidambar orientalis, Cupressus arizonica and the clone Populus x euramericana cv. 'I-45/51') presents are due to the strong pruning (which means pruning almost all the branches of the crown), which resulting in the development of tufts of branch shoots. These branch shoots had desiccation problems because of self-thinning, which is a functional reaction of the tree to the 
excessive increase of branches. This problem is intensified by the insufficient soil conditions. In the case of Cupressus arizonica, the existence of dry and broken branches is due to the early ageing that this species presents because it grows fast. With regard to the pruning of the species Celtis australis, Albizia julibrissin and Liquidambar orientalis, it is recommended that it should be avoided, but when this is necessary it should be done according to the guidelines laid down for pruning.

It may be said that the biggest density of greenery is present in Nikis Avenue, which consists of Platanus orientalis, because the values of the greenery's surface and volume indicators are the highest in this avenue. This conclusion results from the fact that the trees of Platanus orientalis have the largest average values of height, crown's beginning height, crown projection and breast diameter in relation to the trees in the other roads. Egnatia Street has small a greenery volume because of its narrow pavements which prohibit the right growth of the trees. It is suggested that the trees should not be pruned unless it is necessary and the gaps between the street trees should be filled by using the species Celtis australis, which is a very suitable species for the urban environment of Thessaloniki. Karamanli Avenue also has a small greenery volume with unsuitable species. The poplar and cypress must be removed and substituted by a suitable urban-friendly species. The former because it is susceptible to branch breakage by windfall, a dangerous outcome for citizens and cars. The latter because its crown presents thinning caused by the pollution in urban environments.

With regard to the linear model that concerns the greenery's volume indicator $[Y=-104.048+$ $14.64 X_{1}$ (tree height) $-18.73 X_{2}$ (crown's beginning height) $+3.48 X_{3}$ (crown projection)], it is observed that the mathematical signs can be interpreted in real terms. The volume indicator increases with the increase in height and with the increase in crown projection and decreases with the increase in crown's beginning height because the crown length decreases. There is also a good adaptation of the model to our data, because tree variables were especially correlated with the tree volume indicator, explaining $93.5 \%$ of the model variance. Thus, this model may help in the estimation of the greenery volume in urban ecosystems.

\section{REFERENCES}

[1] Girardet, H., The GAIA Atlas of Cities: New Directions for Sustainable Urban Living, Anchor Books/Doubleday: New York, 1992.

[2] EEA, Europe's Environment: The Dobris Assessment, eds D. Stanners \& Ph. Bourdeau, European Environment Agency: Copenhagen, 1995.

[3] Konijnendijk, C.C., Urban forestry: overview and analysis of European forest policies. Part 1. Conceptual framework and European urban forestry history. EFI Working Paper 12. European Forest Institute, Joensuu, 1997.

[4] Konijnendijk, C.C., Urban woodland conservation management and development in Europe - a comparative study. COST Action E12 "Urban Forests and Trees". Proceedings No 1, Office for Official Publications of the European Communities: Luxemburg, 1998.

[5] EEA, State of the European Environment, European Environment Agency: Copenhagen, 1998.

[6] Kuchelmeister, G., Urban green for local needs - improving quality of life through multipurpose urban forestry in developing countries. Proceedings of the First International Conference on Quality of Life in Cities, March 4-6, Singapore, Vol. 1, pp. 181-191, 1998.

[7] Konijnendijk, C.C., Adapting forestry to urban demands - role of communication in urban forestry. Landscape and Urban Planning, 52, pp. 89-100, 2000. doi:10.1016/S0169-2046(00)00125-0

[8] Grahn, P., Man's Needs for Urban Parks, Greenery and Recreation, Institute for Landscape Planning, Swedish Agricultural University, Alnarp, 1985.

[9] Hartig, T., Mang, M. \& Evans, G., Restorative effects of natural environments experiences. Environ. Behav., 23, pp. 3-26, 1991. doi:10.1177/0013916591231001 
[10] Godbey, G., Grafe, A. \& James, W., The Benefits of Local Recreation and Park Services. A Nationwide Study of the Perceptions of the American Public, College of Health and Human Development, Pennsylvania State University, Pennsylvania, 1992.

[11] Kuo, F.E., Bacaioca, M. \& Sullivan, W.C., Transforming inner city landscapes: trees, sense of safety, and preferences. Environ. Behav., 30, pp. 28-59, 1998. doi:10.1177/0013916598301002

[12] Chiesura, A., The role of urban parks for the sustainable city. Landscape and Urban Planning, 68, pp. 129-138, 2004. doi:10.1016/j.landurbplan.2003.08.003

[13] Tsitsoni, Th. \& Samara, Th., The existing situation and management of urban forests and trees in western Macedonia. Proceedings of the 10th Panhellenic Forest Science Conference, May 26-29, Tripoli, Greece, pp. 136-147, 2002 (in Greek).

[14] Grey, G.W. \& Deneke, F.J., Urban Forestry, 2nd edn, Krieger Publishing Company: Malabar, FL, 1986.

[15] Nilsson, K. \& Randrup, T.B., Urban and periurban forestry. Proceeding of the XI World Forestry Congress, 13-22 October 1997, Antalya, Volume 1: Forest and Tree Resources, pp. 97-110, 1997.

[16] Randrup, T.B., Konijnendijk, C.C. \& Andersen, F., Review of higher education on urban forestry in Europe. Report of COST Action E12 "Urban Forests and Trees", Office for Official Publications of the European Communities: Luxemburg, 2001.

[17] Randrup, T.B., Konijnendijk, C.C., Christophersen, T. \& Nilsson, K., COST Action E12 "Urban Forests and Trees". Proceedings No 1, Office for Official Publications of the European Communities: Luxemburg, 2002.

[18] http://www.hellenic-landscapes.gr (accessed August 28, 2005).

[19] Ganatsas, P., Tsitsoni, Th., Zagas, Th. \& Tsakaldimi, M., Evaluation of the urban green space in Thessaloniki city. Proceedings of the 10th Panhellenic Forest Science Conference, May 26-29, Tripoli, Greece, pp. 627-637, 2002 (in Greek).

[20] Tsitsoni, Th. \& Zagas, Th., Estimation of adaptability of tree species on the basis of tree condition and human activities. Proceedings of the Urban Greening and Landscape Architecture Research Symposium, ed. T.B. Rundrup, June 23-25, Copenhagen, Demark, Vol. 2, pp. 58-59, 1999.

[21] Beatty, R.A. \& Heckman, C., Survey of municipal tree systems in the United States. Urban Ecology, 5, pp. 81-102, 1981. doi:10.1016/0304-4009(81)90002-4

[22] Kuchelmeister, G., Urban and peri-urban multipurpose forestry in development cooperation experience, deficits and recommendations. Funded by the Commission of the European Communities, Illertissen, Germany, Unpublished final report, 1991.

[23] Kuchelmeister, G. \& Braatz, S., Urban forestry revisited. UNASYLVA (Urban and Periurban Forestry), 44(173), 1993.

[24] Samara, Th. \& Tsitsoni, Th., Tree quality control and care measures in urban environment. Proceedings of the 11th Panhellenic Forest Science Conference, October 1-3, Ancient Olympia, Greece, pp. 705-721, 2003 (in Greek).

[25] Tsitsoni, Th. \& Zagas, Th., Silvicultural measures for improved adaptability of tree species to the urban environment. Proceedings of International Conference on Ecological Protection of the Planet Earth, eds. V. Tsihritzis \& Ph. Tsalides, June 5-8, Xanthi, Greece, Vol. 2, pp. 415-422, 2001.

[26] Tsitsoni, Th., Batala, E. \& Zagas, Th., Management of urban green and suggestions for its upgrade in the Municipality of Thessaloniki. Proceedings of the 12th Panhellenic Forest Science Conference, October 2-4, Drama, Greece, pp. 231-242, 2005 (in Greek).

[27] USDA Forest Service, Forest Inventory and Analysis National Core Field Guide. Volume I: Field Data Collection Procedures for Phase 2 Plots, pp. 80-89, 2007. 
[28] USDA Forest Service, Phase 3 Field Guide - Crowns: Measurements and Sampling, Section 12. pp. 5-21, 2002.

[29] Crown cover. http://www.dpi.vic.gov.au/DSE/nrenfor.nsf/FID/0AF90B034A49AE474A2567 F50002146C? OpenDocument (accessed May 16, 2006).

[30] Crown surface area and volume. http://sres-associated.anu.edu.au/mensuration/Brackand Wood1998/CROWN.HTM\#volume (accessed May 16, 2006).

[31] Dafis, Sp., Urban Forestry, Art of Text: Thessaloniki, Greece, p. 198, 2001 (in Greek).

[32] Tukey, J., Exploratory Data Analysis, Addison-Wesley Publishing Company, 1977.

[33] Matis, K., Forest Biometry I. Statistics, Pigassos Editions: Thessaloniki, Greece, p. 598, 2003 (in Greek).

[34] Basiaux, Ph., Bodson, M., Embo, T., Gobeaux, J.C., Hermy, M., Van Herzele, A. \& Van Slycken, J., Report on the state of the art of Belgium. Research and Development in Urban Forestry in Europe. Report of COST Action E12 "Urban Forests and Trees" on the State of the Art of Urban Forestry Research and Development in Europe, eds M. Forrest, C.C. Konijnendijk \& T.B. Randrup, Office for Official Publications of the European Communities: Luxemburg, ISBN 92-828-7578-4, pp. 38-54, 1999.

[35] Forrest, M., Konijnendijk, C.C. \& Randrup, T.B. (eds), Research and Development in Urban Forestry in Europe. Report of COST Action E12 "Urban Forests and Trees" on the State of the Art of Urban Forestry Research and Development in Europe, Office for Official Publications of the European Communities: Luxemburg, ISBN 92-828-7578-4, 1999.

[36] Duhme, F., Dujesiefken, D. \& Pauleit, S., Report on the state of the art of Germany. Research and Development in Urban Forestry in Europe. Report of COST Action E12 "Urban Forests and Trees" on the State of the Art of Urban Forestry Research and Development in Europe, eds M. Forrest, C.C. Konijnendijk \& T.B. Randrup, Office for Official Publications of the European Communities: Luxemburg, ISBN 92-828-7578-4, pp. 121-141, 1999.

[37] Collins, K.D., Forrest, M. \& O'Sullivan, R., Report on the state of the art of Ireland. Research and Development in Urban Forestry in Europe. Report of COST Action E12 "Urban Forests and Trees" on the State of the Art of Urban Forestry Research and Development in Europe, eds M. Forrest, C.C. Konijnendijk \& T.B. Randrup, Office for Official Publications of the European Communities: Luxemburg, ISBN 92-828-7578-4, pp. 178-192, 1999.

[38] Rach, I., Schmidt, G. \& Varga, G., Report on the state of the art of Hungary. Research and Development in Urban Forestry in Europe. Report of COST Action E12 "Urban Forests and Trees" on the State of the Art of Urban Forestry Research and Development in Europe, eds M. Forrest, C.C. Konijnendijk \& T.B. Randrup, Office for Official Publications of the European Communities: Luxemburg, ISBN 92-828-7578-4, pp. 157-165, 1999.

[39] Gustavsson, R., Axelsson-Lindgren, C., Lindholm, G., Lindqvist, H. \& Rolf, K., Report on the state of the art of Spain. Research and Development in Urban Forestry in Europe. Report of COST Action E12 "Urban Forests and Trees" on the State of the Art of Urban Forestry Research and Development in Europe, eds M. Forrest, C.C. Konijnendijk \& T.B. Randrup, Office for Official Publications of the European Communities: Luxemburg, ISBN 92-828-7578-4, pp. 273-293, 1999.

[40] Lindén, L., Löfström, I. \& Tyrväinen, L., Report on the state of the art of Finland. Research and Development in Urban Forestry in Europe. Report of COST Action E12 "Urban Forests and Trees" on the State of the Art of Urban Forestry Research and Development in Europe, eds M. Forrest, C.C. Konijnendijk \& T.B. Randrup, Office for Official Publications of the European Communities: Luxemburg, ISBN 92-828-7578-4, pp. 76-107, 1999. 